\title{
ANTIBACTERIAL POTENTIAL OF BROWN ALGAE (SARGASSUM POLYCYSTUM) BACTERIAL SYMBIONT FROM COASTAL AREA IN BANTEN BAY, SERANG MUNICIPALITY, BANTEN OF INDONESIA
}

\author{
Nurseha Atik, Dharmayanti Niken*, Nurbani Siti Zachro, Salampessy Randi B.S., \\ Siregar Arpan N., Permadi Aef, Sipahutar Yuliati, Hidayat Tatang Taufiq \\ Fish Processing Technology Study Program, Department of Fish Processing Technology, \\ Sekolah Tinggi Perikanan, Jakarta, Indonesia \\ *E-mail: niken.stp@gmail.com
}

\begin{abstract}
Brown algae are less popular and very few people pay attention to the plant; the algae are scattered on coastal areas and people treat them like garbage. Brown alga has as many nutrient contents and benefits as other types of algae. Objective of this research is to describe antibacterial potential of brown algae (Sargassum polycystum) bacterial symbiotic by isolating the brown algae bacterial symbiont with biossay method and conducting the challenge test using S.aureus and E.coli bacteria. The findings showed that brown algae (Sargassum polycystum) have potential for antibacterial by isolating a total of isolate 24 antibacterial compound-producing isolates, namely 7 isolates from surface of the algae and 17 isolates from inside of the algae. Qualitative challenge test found that 1 isolate (sa B1L) from the surface of the algae and 4 isolates (Sa B2D, sa B3D, sa B4D, sa B5D) from inside the algae can inhibit growth of E.coli and S.aureus.
\end{abstract}

\section{KEY WORDS}

Sargassum polycystum, bacterial symbiont, antibacterial potential.

We are blessed with various types of marine organism because $70 \%$ of the world is covered by sea. A type of marine organism that human being can use is macro algae or commonly known as seaweed (Ritonga, et.al, 2014). Seaweed is categorized into 3 classes, namely Chlorophyta (green seaweed), Phaeophyta (brown seaweed) and Rhodophyta (red seaweed). Each class contains certain pigment. Seaweed has primary and secondary metabolites. Primary metabolites consist of vitamin, mineral, fiber, alginate, carrageenan and agar. Besides the primary metabolite that has economic value, seaweed secondary metabolites such as tannins, phenol, saponins, alkaloids, flavonoids, and steroid produce various bioactive metabolite, which has several activities, namely as antibacterial, antiviral, antifungal and cytotastic (Zainunddin and Malina, 2009).

Marine algae try to develop a self-defense mechanism to fight pathogenic organisms in the sea. One general mechanism is to produce chemical compounds that are toxic to predators, including antibacterial active compounds. It is very likely that host organism, symbiont which is symbiotic with the host or both the host and the symbiont is responsible for producing the active compound (Nendissa, M, 2012).

A lot of research investigating benefits of seaweed based on microbiological perspective investigated microorganisms that are symbiotic with seaweed and can produce certain metabolites such as antimicrobials (Jafriati, 2014). Several recent studies have shown that seaweed micro-symbiotant can be one of the sources of bioactive compounds, but seaweed cells themselves can also produce these metabolites (Jafriati, 2014). Previous research on brown algae (Sargassum $\mathrm{sp}$ ) reported that brown algae has antimicrobial potential in the form of bioactive protein from bacteria that are symbiotic with the algae (Sartika, et.al, 2014). Based on Pigment Test analyzing total carotenoid pigment extract and echinenone-type pigment of brown algae (Sargassum polycystum), 4 out 15 bacteria tested showed has antibacterial activity (Paransa, et.al, 2014). Sargassum polycystum extract from ethyl acetate solvent has the best antibacterial activity against Vibrio harveyi and micrococcus luteus bacteria (Riyanto, et.al, 2013). 
Objective of this study is to describe antibacterial potential of brown algae (Sargassum polycystum) bacterial symbiont by isolating and selecting which brown algae (Sargassum polycystum) bacterial symbiont that produces antibacterial compounds and to describe characteristics of the bacterial symbiont obtained.

\section{MATERIALS AND METHODS OF RESEARCH}

Equipments used in this study were autoclave (Ikemoto scientific 10-908 KT $30 \mathrm{~L}$ ), hot plate (Thermo scientific), digital scale (Vibra), refrigerator (Selecta), Oven (Memmert), incubator (Memmert), Microscope (Olympus Cx 21-FX1), shaker (Thermo scientific), Laminary flow (Teistar AV-100), centrifugation (Eppendorf), vortex mixer (Heidolph), pipette (Pyrex), erlenmeyer (Pyrex), measuring cup (Hokkai), petri dish (Anormax), pipette pump (Bel-Art), 10-100 $\mu \mathrm{l}$ micropipette (Omnipette), $50 \mu \mathrm{l}$ micropipette (Finnipette), and reaction tube (Baiel). Furthermore, materials used in the study are Sargassum polycystum from Pulau Lima waters, Eschericia coli and Staphylococcus aureus pure culture from Biological Laboratory of Bandung Institute of Technology, sterilized sea water, $13 \mathrm{gr} / \mathrm{L}$ of Nutrien broth (Oxoid), $17.5 \mathrm{gr} / \mathrm{L}$ of Plate Count Agar (Oxoid), $38 \mathrm{gr} / \mathrm{L}$ of Muller Hinton Agar (Oxoid), urea broth (Merck), mannitol (Difco), coser citrate (Difco), arabinose (Merck), gelatin (Merck), glucose (Merck), safranin (Merck), crystal violet (Merck), malachit green (Merck), phenol red broth base (Merck), fuchsin (Merck), alcohol (Brataco chemica), $\mathrm{H}_{2} \mathrm{O}_{2}$ (from Chemical Laboratory of Nasional Jakarta University), HDPE plastic (Bell), cotton (Sari bunga), rubber (Rubber band), and immersion oil (Olympus corporation).

The study was conducted between February 6 and May 6, 2017 in Microbiology Laboratory of Higher Institute of Fisheries of Jakarta. Sargassum polycystum samples were taken from coastal are of Banten Bay, Serang Municipality, Banten. Seaweed identification was conducted in Center of Oceanographic Research - Indonesian Institute of Science, DKI Jakarta.

Sargassum polycystum was obtained from coastal area of Banten Bay located in Pulau Lima, Serang Municipality. The samples were stored in clean containers filled with salt water from Sargassum polycystum habitat. The samples were then taken to the Microbiology Laboratory of Higher Institute of Fisheries of Jakarta.

Surface of algae: 15 grams of the samples were rinsed with $30 \mathrm{ml}$ of sterilized salt water. The water was poured into $30 \mathrm{ml}$ of Nutrien Broth and shaken using a shaker at 140 rpm at room temperature for 24 hours.

Inside of Algae: 15 grams of the samples were rinsed with $30 \mathrm{ml}$ of sterilized salt water, ground using a mortar and pestle and sterilized salt water was poured into the pestle. Suspension was poured into $30 \mathrm{ml}$ of NB and shaken using a shaker at $140 \mathrm{rpm}$ at room temperature for 24 hours.

Having refreshed in NB, the samples were diluted gradually between $10^{-1}$ and $10^{-5}$. Each dilution was grown in PCA with temperature of $37^{\circ} \mathrm{C}$ for $2 \times 24$ hours. Bacteria with stable transparent zone were harvested and scratched with the quadrant method to obtain a single colony.

Took \pm 1 ose of E.coli and S.aureus pure culture and inoculated the culture on $10 \mathrm{ml}$ of Nutrient Broth (NB). Incubated the culture at $37^{\circ} \mathrm{C}$ for 24 hours.

Took \pm 1 ose of bacterial symbiont pure culture from each code, and inoculated the culture on tilted Plate Count Agar (PCA). Incubated the culture at $37^{\circ} \mathrm{C}$ for 24 hours.

The following step was to conduct qualitative direct challenge test by scratching and spraying isolate onto Muller Hinton Agar (MHA) surface. $10 \mu$ bacteria required $10 \mathrm{ml}$ of liquid muller hinton agar (MHA). Bacteria-filled agar was vortexed or homogenized, poured into sterilized petri dish immediately and shaken to form number eight in order that the bacteria spread evenly. The media is sat to harden. The next step is conducting challenge test by scratching and spraying isolate on surface of media in which testing bacteria (E.coli and S.aureus) had been spread previously. The media were incubated for $2 \times 24$ hours under temperature of $37^{\circ} \mathrm{C}$. 
Macroscopic observation helped the researchers identifying color (shape, edge, elevation and color) of bacterial colony.

Gram staining provides better results when researchers use fresh cultures (24 to 48hour culture). Gram staining was conducted by making preparate, fixing it on fire, pouring crystal violet solution and resting it for 1 minute, washing it with running water, pouring lugol solution and resting it for 1 minute, pouring bleach solution for 10-20 seconds, washing it with water, pouring Safranin solution and resting the solution 15 seconds, washing it with water, drying and observing it under a 100x microscope.

\section{RESULTS AND DISCUSSION}

Brown Algae (Sargassum polycystum) Bacterial Symbiont Isolation. The results findings showed that brown algae (Sargassum polycystum) brown algae can isolate 24 antibacterial compound-producing isolates, namely 7 isolates from surface of the algae and 17 isolates from inside of the algae; each is obtained from $10^{-4}$ dilution. From surface of the samples, the researchers identified 7 isolat and they were inoculated into 2 isolates that had the largest transparent zone on the surface of the algae (sa B1L, sa B2L). From the inner side of the samples, the researchers identified 17 isolates and they were inoculated into 5 isolates with the largest transparent zone on the inside of the algae (sa B1D, sa B2D, sa B3D, sa B4D, sa B5D). Objective of inoculation is to grow, rejuvenate microbes and obtain pure microbes. Pastra, et.al (2012) stated that bacterial isolate purification aims to separate bacterial isolation result that consists of different types of bacterial colonies and obtain pure bacterial colony from each bacterial culture. Dominant colonies are those being harvested and purified. Scratching was method for purification. Figure 1 showed result of isolation.

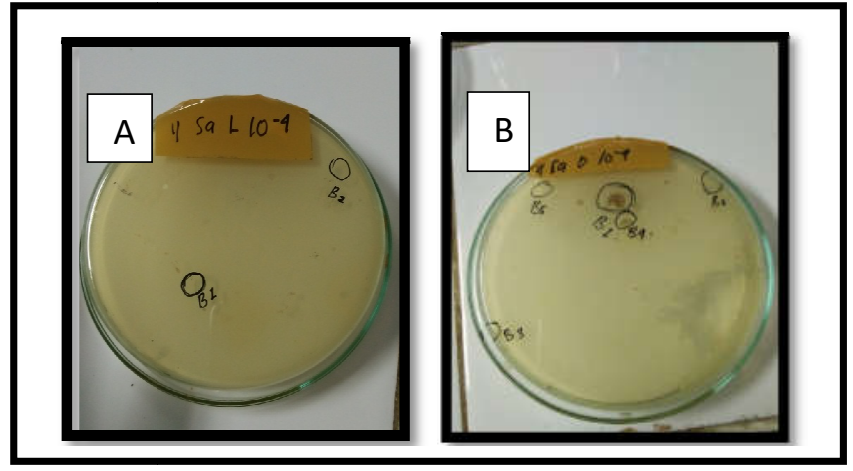

Figure 1 - Sargassum polycystum Bacterial Symbiont Isolation (A. Purified Surface Isolate; B. Purified Inner Isolate)

Antibacterial Compound-Producing Isolate Selection (Challenge Test). Based on the challenge test, 5 bacteria developed zones to inhibit E.coli and S.aureus from spreading further. 1 bacterial isolate from the surface of the samples (B1L sa code) and 4 bacterial isolates from the inside of the samples (sa B2D, sa B3D, sa B4D and sa B5D) showed antibacterial activity against pathogenic bacteria. It was characterized by a clear zone in the isolate. Bacterial isolates on the surface are ones associated to seaweed. Bacteria from the surface of the population are fewer in number due to availability of nutrients and they require higher defense power to overcome competitors, predators or others. On the other hand, bacteria from the inside of the seaweed have higher population because the inside part of the algae has a lot more and various nutrients available.

Bacterial isolate obtained from the inside of the sample has better inhibitory zone rather than that obtained from the surface of the sample. Abubakar, et.al (2011) stated that bacterial symbiont obtained from the inside of algae is generally higher in number and is a specific microbe because it has direct interaction with bioactive compound the algae produce. At the opposite, bacterial symbiont obtained from the surface of algae is fewer in 
number because it requires higher immunity to overcome pathogen and predator around the algae.

Cappucino and Sherman (1986) as cited in Rizka (2008) are used to observe morphological colony of the bacteria with each code, either from the surface or inside part of the algae.

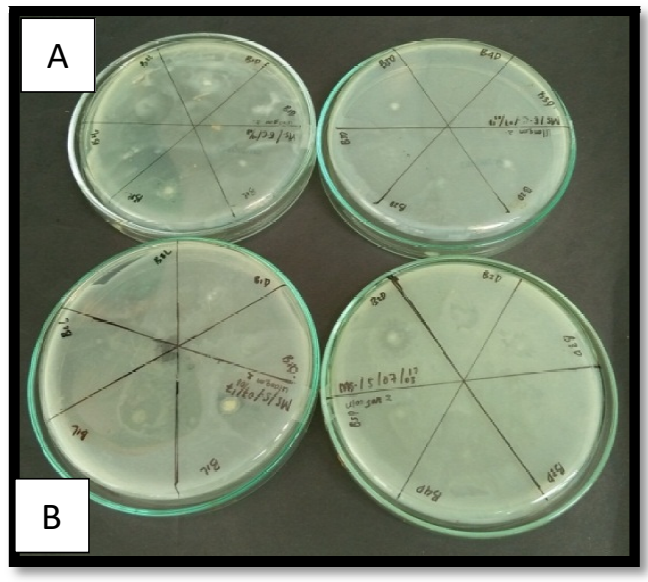

Figure 2 - Challenge Test (Code A: Challenge Test on the E.coli; Code B: Challenge Test on the S.aureus)

Table 1 - Result on Bacterial Symbiont Colony Morphological Observation

\begin{tabular}{|c|c|c|c|c|}
\hline \multirow{2}{*}{ Isolate Code } & \multicolumn{3}{|c|}{ Morphological Characteristics of Colony } \\
\cline { 2 - 5 } & Shape & Edge & Elevation & Color \\
\hline Sa B1L & Round & Intact & Convex & Yellow \\
\hline Sa B2D & Round & Intact & Convex & Milky white \\
\hline Sa B3D & Round & Intact & Convex & Milky white \\
\hline Sa B4D & Round & Intact & Convex & Milky white \\
\hline Sa B5D & Irregular shape & Surging & Flat & Milky white \\
\hline
\end{tabular}

The table above showed that majority of the bacterial colonies (sa B2D, sa B3D, sa B4D, sa B5D) were round and milky white. 1 isolate colony had a different color, namely isolate colony of which code was sa B1L (yellow). The isolates were obtained from the surface of the algae. In other words, color is influenced by part of the algae from which the colony is obtained. According to Ramadhan (2012), differences in color of bacterial colonies occur due to differences in intracellular pigments produced by the bacteria.

Table 2 - Result of Challenge Test to Obtain Selected Bacteria

\begin{tabular}{|c|c|c|}
\hline \multirow{2}{*}{ Isolate Code } & \multicolumn{2}{|c|}{ Challenge Test (24 hours) } \\
\cline { 2 - 3 } & E.coli $(\mathrm{mm})$ & S.aureus $(\mathrm{mm})$ \\
\hline Sa B1L & 2.03 & 1.3 \\
\hline Sa B2D & 2.69 & 4.52 \\
\hline Sa B3D & 2.95 & 5.55 \\
\hline Sa B4D & 1.98 & 4.61 \\
\hline Sa B5D & 1.72 & 3.76 \\
\hline
\end{tabular}

Based on the largest inhibition zone formed against E.coli and S.aureus (Table 2), each bacterial symbiont isolate had a varying degree of inhibition. Table 2 also showed that bacterial isolates with sa B3D code had the highest inhibitory effect on E.coli $(2.95 \mathrm{~mm})$ and S.aureus $(5.55 \mathrm{~mm})$ compared to the other isolates. According to Sutia (2011), higher diameter of inhibitory zone indicated higher resistance towards certain bacterial isolates. Furthermore, the sa B3D code isolate obtained from the inside of the Sargassum polycystum algae were used as selected isolate that identified isolates of bacterial symbiont of algae. According to Rizka (2008), an antagonistic test was used to evaluate ability of symbionous 
bacterial isolates to kill pathogenic bacteria. Ability to kill pathogenic bacteria can be characterized by clear zones formed around bacterial scratches; it proved that a tested pathogenic bacterium cannot grow anymore.

Macroscopic observation helps identifying shape, edge, elevation and color of bacterial colony. The researchers used this method to identify morphological characteristics of Sargassum polycystum bacterial symbiont isolates including its color. Table 1 showed result of the observation.

Gram staining is used to identify clear zones developed on the isolate. Table 3 showed result of the Gram staining.

Table 3 - Morphological Observation using Microscope

\begin{tabular}{|c|c|c|}
\hline Bacterial Isolate Code & Shape & Category (after Gram staining) \\
\hline Sa B1L & Rod-shaped & Gram Positive \\
\hline Sa B2D & Rod-shaped & Gram Positive \\
\hline Sa B3D & Rod-shaped & Gram Positive \\
\hline Sa B4D & Rod-shaped & Gram Positive \\
\hline Sa B5D & Rod-shaped & \\
\hline
\end{tabular}

\section{CONCLUSION}

Bacterial symbiont isolate from Sargassum polycystum (brown algae) from the water in Banten Bay consists of 24 isolates, 7 isolates from the surface of the algae and 17 isolates from the inside of the algae.

Based on challenge test, there are 5 isolates that can inhibit growth of S.aureus and E.coli, 1 isolate from the surface of the algae and 4 isolates from the inside of the algae.

Isolate obtained from Sargassum polycystum (brown algae) is categorized as gram positive bacteria.

Further researchers should identify phenotypes, genotypes and characteristics of secondary metabolites produced by Sargassum polycystum (brown algae) bacterial symbiont.

\section{REFERENCES}

1. Ritonga W. S, Fajri F. N, Ridwan Y. A, Putri M. A. 2014. DNA barcodes for marine biodiversity: determinasi dan identifikasi alga merah (Rhodophyta) dipantai Cipatuhuh Tasikmalaya melalui identifikasi molekuler DNA barcoding. Research Report of Bachelor Degree Students. Bogor Institute of Agriculture.

2. Zainuddin, E. N \& Malina, A C. 2009. Skrinning Rumput Laut Asal Sulawesi Selatan Sebagai Antibiotik Melawan Bakteri Patogen pada Ikan. Research Report for Research Grant. Biaya Imhere-Dikti.

3. Nendissa, M.D. 2012. Analisa Kemampuan Alga Hijau Silpau (Dictyosphaetria Versluysii) Sebagai Antibakteri. Jurnal Ekosains. Vol.1,No.1-hal. 47-52

4. Jafriati. 2014. Isolasi bakteri Penghasil antibiotika dari rumput laut Thalassia hemprichii yang tumbuh dipulau barang lompo sulawesi selatan. Jurnal ilmiah kesehatan masyarakat. Faculty of Public Health, Haluoleo University.

5. Riyanto I.E., Widowati, I., Sabdono, A. 2013 Skrining Aktivitas Antibakteri pada Ekstrak Sargassum polycystum Terhadap bakteri Vibrio harveyi dan Micrococcus luteus di Pulau Panjang Jepara. Journal Of Marine Research.Volume, Nomor, Tahun 2013, Halaman 115-121, Online di: http://ejournal-s1.undip.ac.id/index.php/jm

6. Sartika, Ahmad, A., Natsir, H., 2014. Potensi Antimikroba Protein Bioaktif dari Bakteri Simbion Alga Coklat Sargassum sp. Asal Perairan pulau Lae-Lae. Jurnal Penelitian Universitas Hasanuddin, http://repository.unhas.ac.id/handle/123456789/10016

7. Pastra, D.A., Surbakti M.H., 2011. Penapisan Bakteri yang Bersimbiosis dengan Spons Jenis Aplysina sp. Sebagai Penghasil Antibakteri dari Perairan Pulau Tegal Lampung. MASPARI JOURNAL, 4(1): 77-82. 
8. Abubakar, H., Wahyudi, A.T. and Yuhana, M., 2011. Pengaruh Kepadatan Berbeda Terhadap Kelulusan Hidup Ikan Betatu (Oxyeleotris Masmorata Blks). Pada Pengangkutan Sistem Tertutup. Jurnal Saintek Perikanan Vol. 7 no.1. 2011.

9. Sutia, R.B., Soedharma, D., Ismet, M.S., 2011. Penapisan Bakteri Asosiatif Karang Lunak (Octocorallia: Alcyonacea) Silunaria dura Dan Labophytum Sctrictum yang potensial sebagai alternatif penanganan mikrofouling di laut. Bogor Institute of Agriculture. http://repository.ipb.ac.id/handle/123456789/54001

10. Rizka, A. 2013. Skrinning Bakteri Simbion Spons Asal Pearairan Pulau Polewali dan Pulau Sarappolompo Sebagai Penghasil Antibakteri Terhadap Bakteri Patogen Pada Manusia dan Ikan. Unpublished Thesis. Fakultas IImu Kelautan dan Perikanan, Hasanuddin University.

11. Paransa, D.S.J., Kemer, K., Rumengan, A.P., Mantiri, D.M.H., 2014. Analisis Jenis Pigmen dan Uji Aktivitas Antibakteri Ekstrak Pigmen Xantofil pada Alga Coklat Sargassum polycystum (C.Agardh). Jurnal LPPM Bidang Sains dan Teknologi, Volume 1, No. 1, pp. 1-7. 